\title{
Investigation of receptor binding and functional characteristics of hemopressin(1-7)
}

\author{
Szabolcs Dvorácskó a , Csaba Tömböly ${ }^{\mathrm{a}}$, Róbert Berkecz ${ }^{\mathrm{b}}$, Attila Keresztes ${ }^{\mathrm{a}, *}$ \\ a Laboratory of Chemical Biology, Institute of Biochemistry, Biological Research Centre of the Hungarian Academy of Sciences, Szeged, Hungary \\ b Department of Medical Chemistry, University of Szeged, Szeged, Hungary
}

\section{A R T I C L E I N F O}

Article history:

Received 20 August 2015

Received in revised form 1 February 2016

Accepted 1 February 2016

Available online $\mathrm{xxxx}$

\section{Keywords:}

Hemopressin

Tritium labeling

Cannabinoid receptor

Radioligand binding assay

Ligand stimulated $\left[{ }^{35} \mathrm{~S}\right] \mathrm{GTP} \gamma \mathrm{S}$ binding assay

\begin{abstract}
A B S T R A C T
The orally active, $\alpha$-hemoglobin derived hemopressin (PVNFKFLSH, $\mathrm{Hp}(1-9))$ and its truncated (PVNFKFL, $\mathrm{Hp}(1-7)$ and PVNFKF, $\mathrm{Hp}(1-6)$ ) and extended ((R)VDPVNFKFLSH, VD-Hp(1-9) and RVD-Hp(1-9)) derivatives have been postulated to be the endogenous peptide ligands of the cannabinoid receptor type 1 (CB1). In an attempt to create a versatile peptidic research tool for the direct study of the CB1 receptor-peptide ligand interactions, $\mathrm{Hp}(1-7)$ was radiolabeled and in vitro characterized in rat and CB1 knockout mouse brain membrane homogenates. In saturation and competition radioligand binding studies, $\left[{ }^{3} \mathrm{H}\right] \mathrm{Hp}(1-7)$ labeled membrane receptors with high densities and displayed specific binding to a receptor protein, but seemingly not to the cannabinoid type 1 , in comparison the results with the prototypic JWH-018, AM251, rimonabant, $\mathrm{Hp}(1-9)$ and RVD$\mathrm{Hp}(1-9)$ (pepcan 12) ligands in both rat brain and CB1 knockout mouse brain homogenates. Furthermore, functional $\left[{ }^{35} \mathrm{~S}\right] \mathrm{GTP} \gamma \mathrm{S}$ binding studies revealed that $\mathrm{Hp}(1-7)$ and $\mathrm{Hp}(1-9)$ only weakly activated G-proteins in both brain membrane homogenates. Based on our findings and the latest literature data, we assume that the $\mathrm{Hp}(1-7)$ peptide fragment may be an allosteric ligand or indirect regulator of the endocannabinoid system rather than an endogenous ligand of the $\mathrm{CB} 1$ receptor.
\end{abstract}

(c) 2016 Elsevier Ltd. All rights reserved.

\section{Introduction}

The endogenous, phyto- and synthetic cannabinoids exert their pharmacological effects through the activation of cannabinoid receptors. To date, the cannabinoid type 1 (CB1) and cannabinoid type 2 (CB2) receptors have been cloned that belong to the superfamily of $\mathrm{G}_{\mathrm{i}} / \mathrm{G}_{\mathrm{o}} \mathrm{G}$-protein coupled receptors (Begg et al., 2005; Pertwee, 1997). The $\mathrm{CB} 1$ receptors are primarily expressed in regions of the central nervous system (Herkenham et al., 1990; Matsuda et al., 1990) while CB2 receptors proved to be localized mainly in immune cells of the periphery (Munro et al., 1993), though recent studies reported the presence of CB2 receptors in the brain stem and spinal cord as well (Van Sickle et al., 2005; Zhang et al., 2003).

Abbreviations: AM251, 1-(2,4-dichlorophenyl)-5-(4-iodophenyl)-4-methyl- $N$-(1 piperidyl)pyrazo-le-3-carboxamide; BSA, bovine serum albumin; DAMGO, [D-Ala ${ }^{2}, \mathrm{~N}$ MePhe $^{4}$, Gly-ol]-enkephalin; DIEA, diisopropylethylamine; DMF, dimethylformamide; EGTA, ethylene glycol-bis(2-aminoethylether)- $N, N, N^{\prime}, N^{\prime}$-tetraacetic acid; EtOH, ethanol; GDP, guanosine $55^{\prime}$-diphosphate sodium salt, type I; GTP $\gamma S$, guanosine $5^{\prime}-[\gamma-$ thio]triphosphate tetralithium salt; Hp, hemopressin; HPLC, high performance liquid chromatography; JWH-018, naphthalen-1-yl(1-pentyl-1H-indol-3-yl)methanone; $i \mathrm{PrOH}$, 2-propanol; Rimonabant, 5-(4-chlorophenyl)-1-(2,4-dichloro-phenyl)-4-methyl- $\mathrm{N}$ (piperidin-1-yl)-1H-pyrazole-3-carboxamide; TFA, trifluoroacetic acid; TBTU, $O$ (benzotriazol-1-yl)- $N, N, N^{\prime}, N^{\prime}$-tetramethyluronium tetrafluoroborate.

* Corresponding author at: Laboratory of Chemical Biology, Institute of Biochemistry, Biological Research Centre of the Hungarian Academy of Sciences, Szeged H-6701, P.O. Box 521, Hungary.

E-mail addresses: keratti@brc.hu, keresztes.attila@mta.ttk.hu, keresztes@email.arizona.edu (A. Keresztes).
Lipid endocannabinoids are the best characterized endogenous ligands of the cannabinoid receptors and their physiological effects are primarily mediated through the CB1 receptors (Di Marzo and Petrosino, 2007; Boyd, 2006). The activation of the CB1 receptor is thought to be responsible for the mediation of antinociception, hypothermia, hypotension, sedation and inhibition of locomotor activity (Manzanares et al., 1999, Massi et al., 2001). Consequently, drugs acting on the $\mathrm{CB} 1$ receptor and on the entire endocannabinoid system may have therapeutic potential in a number of pathological conditions such as obesity, metabolic syndromes, mood and anxiety disorders, neuropathic pain, inflammation, multiple sclerosis, spinal cord injuries, myocardial infarction, stroke, hypertension, cancer and osteoporosis (Pacher et al., 2006).

Over the past decades, the lipid derived endocannabinoids were believed to be the sole endogenous agonists of the cannabinoid receptors. However, as a result of the pioneering works of Heimann et al. (2007) and Rioli et al. (2003), hemopressin (PVNFKFLSH, Hp(1-9)) was identified as a putative inverse agonist peptide ligand of the $\mathrm{CB} 1$ receptor. This peptide is a metabolic product of the hemoglobin $\alpha$-chain and it was demonstrated to exert non-opioid antinociceptive effects, similar to those of the endo-, phyto- and synthetic cannabinoids (Heimann et al., 2007; Hama and Sagen, 2011). In an in vivo model of arthritic pain $\mathrm{Hp}(1-9)$ failed to mitigate mechanical allodynia (Petrovszki et al., 2012), however, in other studies, it could prevent carrageen- and bradykinin-induced hyperalgesia (Dale et al., 2005) and chronic constriction injury-induced mechanical hyperalgesia, a model of neuropathic pain (Toniolo et al., 2014a, 2014b). Hp(1-9) was also reported 
to induce weak, but dose-dependent hypotensive effects and to reduce food intake in rodents via a CB1 receptor-dependent manner (Blais et al., 2005; Rioli et al., 2003; Dodd et al., 2010, 2013). Very recently, $\mathrm{Hp}(1-9)$ was suggested promoting oligodendrocytic differentiation and maturation of subventricular zone progenitor cells, of which processes have significance in myelination abnormalities (Xapelli et al., 2014).

Soon after the discovery and pharmacological characterization of $\mathrm{Hp}(1-9)$, the RVD- and VD-extended RVD-Hp(1-9) and VD-Hp(1-9) (Gomes et al., 2009), and the $C$-terminally truncated $\operatorname{Hp}(1-6)$ and $\mathrm{Hp}(1-7)$ peptides were identified as potent cannabinoid ligands (Dale et al., 2005). RVD-Hp(1-9) and VD-Hp(1-9) were suggested being agonist ligands of the CB1 receptor. In vivo data for the C-terminally truncated hemopressins demonstrated that $\mathrm{Hp}(1-9)$ was not essential for antinociceptive activity, because $\mathrm{Hp}(1-6)$ and $\mathrm{Hp}(1-7)$ exerted as effective antihyperalgesic effects as the $N$-terminally extended peptides. Further $C$-terminal truncation, however, led to the loss of biological activity (Bomar and Galande, 2012). VD- and RVD-Hps exhibited hypotensive, hypothermic and hypoactive effects at antinociceptive doses, and inhibited bombesin-induced central activation of the adrenomedullary outflow in rats (Tanaka et al., 2014; Han et al., 2014). In addition, central administration of VD-Hp resulted in tolerance to antinociception and stimulated food consumption in a CB1-dependent manner (Han et al., 2014; Pan et al., 2014). The signaling characteristics and regulation of receptor endocytosis of the $\mathrm{N}$-terminally extended peptide fragments were found to be distinct, in part, from those of the classical cannabinoid agonists (Gomes et al., 2009).

Circular dichroism, NMR spectroscopy and molecular docking studies on the $\mathrm{Hp}(1-9)$ and $\mathrm{Hp}(1-6)$ peptides showed that regular turn structures in the central portion of the peptides were essential for an interaction with the receptor, and similarly to the inverse agonist rimonabant the peptides stabilized receptor structures via $\mathrm{H}$-bonds (Scrima et al., 2010). This interaction was assumed to be important for the stabilization of the inactive state of $\mathrm{CB} 1$ receptor and provides structural basis for the explanation of the activity of hemopressin peptides as agonist.

These observations suggest that hemopressins are novel endogenous peptide ligands of the $\mathrm{CB} 1$ receptor, and may have potential for the development of peptide-based research tools or therapeutic agents for the study of the endocannabinoid system or the treatment of cannabinoid-related diseases. In the present study, we report on the synthesis and radiolabeling of the $C$-terminally truncated hemopressin peptide $\mathrm{Hp}(1-7)$ and the direct in vitro pharmacological characterization of the novel radioligand $\left[{ }^{3} \mathrm{H}\right] \mathrm{Hp}(1-7)$ in brain membrane homogenates of rat and CB1 knockout mouse. Our results suggest that the hemoglobin fragment $\mathrm{Hp}(1-7)$ may be a regulator of the endocannabinoid system and that $\left[{ }^{3} \mathrm{H}\right] \mathrm{Hp}(1-7)$ can label either a $\mathrm{CB}$ receptor binding site different from the classical cannabinoid ligand binding site or another membrane protein.

\section{Materials and methods}

The peptides $\mathrm{Hp}(1-7)$ (H-Pro-Val-Asn-Phe-Lys-Phe-Leu-OH), $\Delta \mathrm{Pro}^{1}-\mathrm{Hp}(1-7)$ (H- $\triangle$ Pro-Val-Asn-Phe-Lys-Phe-Leu-OH), $\mathrm{Hp}(1-9)(\mathrm{H}-$ Pro-Val-Asn-Phe-Lys-Leu-Leu-Ser-His-OH) and RVD-Hp(1-9) (H-ArgVal-Asp-Pro-Val-Asn-Phe-Lys-Leu-Leu-Ser-His-OH) were synthesized and purified in our laboratory. The peptide synthesis resins, protected amino acids and the coupling reagent TBTU were purchased from Bachem. Hydrogen fluoride used for the cleavage of the peptides was obtained from PRAXAIR N.V. (Oevel, Belgium). Naloxone and rimonabant were kind gifts of Dr. Sándor Hosztafi (Department of Pharmaceutical Chemistry, Semmelweis University, Budapest, Hungary) and Dr. Sándor Benyhe (Hungarian Academy of Sciences, Biological Research Centre, Institute of Biochemistry, Szeged, Hungary). Analytical grade AM251 was obtained from Cayman Chemicals. TFA and BSA were purchased from Fisher Scientific. Protease inhibitor (cat\#: P2714), GDP, GTP $\gamma S$, anisole, ninhydrin, magnesium chloride, EGTA and Bradford reagent were purchased from Sigma-Aldrich Kft. (Budapest, Hungary). Other reagents were obtained from Molar Chemicals Kft. (Budapest, Hungary) or Merck Kft. (Budapest, Hungary). Tritium gas was obtained from Technobexport (Moscow, Russia). Tritium labeling was carried out in a self-designed vacuum manifold and radioactivity was measured with a Packard Tri-Carb 2100 TR liquid scintillation analyzer using Hionic-Fluor scintillation cocktail of PerkinElmer. Radio-HPLC was performed on a Jasco HPLC system equipped with a Packard Radiomatic 505 TR Flow Scintillation Analyser.

\subsection{Preparation of hemopressins}

The peptide synthesis was carried out manually in a silanized glass reaction vessel. $N^{\alpha}$-Boc-Leu-or $N^{\alpha}$-Boc-His(Tos)-PAM resin $(0.15 \mathrm{mmol}$ ) was swollen for $30 \mathrm{~min}$ in DMF. After Boc-deprotection with neat TFA and subsequent washings (three times with DMF and $i$ PrOH $)$, TBTU activated $N^{\alpha}$-Boc-protected amino acids $(0.45 \mathrm{mmol})$ were added for chain elongation in DMF and the unreacted resinbound peptides were end-capped with an excess of $\mathrm{Ac}_{2} \mathrm{O}$ in the presence of DIEA in DMF. Couplings were monitored with the Kaiser-test (Kaiser et al., 1970). After removal of the $\mathrm{N}$-terminal protecting group, peptides were cleaved from the resin with HF in the presence of anisole. The crude peptide - resin mixtures were washed with diethylether, then the peptides were dissolved in aqueous TFA and lyophilized. The resulting crude peptides were dissolved in aqueous TFA, and introduced onto an analytical Vydac 218TP54 column and eluted using a linear gradient of $1.5 \%$ per min of acetonitrile in water containing $0.1 \%$ TFA, starting from $15 \%$ acetonitrile at a flow rate of $1 \mathrm{~mL} / \mathrm{min}, \lambda=215 \mathrm{~nm}$. The same elution conditions were used for the purification of the peptides on a semipreparative Vydac 218TP1010 column at a flow rate of $4 \mathrm{~mL} / \mathrm{min}$; isolated yields $56 \%(\mathrm{Hp}(1-7)), 74 \%\left(\Delta \operatorname{Pro}^{1}-\mathrm{Hp}(1-7)\right), 38 \%$ $(\mathrm{Hp}(1-9))$ and $42 \%$ (RVD-Hp(1-9)). Molecular weights of the peptides were confirmed by MALDI-TOF mass spectrometry $\left(\mathrm{Hp}(1-7)[\mathrm{M}+\mathrm{H}]^{+}\right.$ 864.42; $\Delta$ Pro $^{1}-\mathrm{Hp}(1-7)[\mathrm{M}+\mathrm{H}]^{+}$862.63; $\mathrm{Hp}(1-9)[\mathrm{M}+\mathrm{H}]^{+}$1089.26; RVD-Hp(1-9) $[\mathrm{M}+\mathrm{H}]^{+}$1424.80).

\subsection{Preparation of $\left[^{3} \mathrm{H}\right] \mathrm{Hp}(1-7)$}

The precursor peptide $\Delta \operatorname{Pro}^{1}-\mathrm{Hp}(1-7)$ ( $\left.2 \mathrm{mg}, 2.32 \mu \mathrm{mol}\right)$ was dissolved in DMF and $3 \mathrm{mg} \mathrm{Pd} / \mathrm{BaSO}_{4}$ catalyst was added to the solution. The reaction mixture was degassed prior to tritium reduction by a freeze-thaw cycle. Then it was stirred under 0.4 bar of tritium gas for $1 \mathrm{~h}$ at ambient temperature, followed by the filtration of the catalyst through a Whatman GF/C glass fiber filter. The filtrate was evaporated and labile tritium was removed by repeated evaporations from aqueous EtOH solution. Finally $2.85 \mathrm{GBq}$ of crude $\left[{ }^{3} \mathrm{H}\right] \mathrm{Hp}(1-7)$ was obtained that was purified by HPLC. Quantitative analyses of the concentration and radioactivity of $\left[{ }^{3} \mathrm{H}\right] \mathrm{Hp}(1-7)$ were performed by RP-HPLC via UV and radioactivity detection using a calibration curve made by $\mathrm{Hp}(1-7)$, and the specific activity of $\left[{ }^{3} \mathrm{H}\right] \mathrm{Hp}(1-7)$ was found to be $1.04 \mathrm{TBq} / \mathrm{mmol}$ (28 Ci/mmol). The radioligand was aliquoted as ethanolic solutions and stored in liquid nitrogen until application.

\subsection{Preparation of brain membrane homogenates}

Wistar rats (male, 180-220 g) were housed locally ad libitum and handled according to the European Communities Council Directives (86/609/ECC) and to the Hungarian Act for the Protection of Animals in Research (XXVIII.tv. Section 32). Crude membrane fractions were prepared from the brain without cerebellum. Brains were quickly removed from the euthanized rats and directly put in ice-cold $50 \mathrm{mM}$ Tris/HCl ( $\mathrm{pH}$ 7.4) buffer. The collected tissue was then homogenized in 30 volumes $(\mathrm{v} / \mathrm{w})$ of ice-cold buffer with a Teflon-glass Braun 
homogenizer at the highest rpm. The homogenate was centrifuged at $20,000 \mathrm{~g}$ for $25 \mathrm{~min}$. The supernatant was discarded and the resulting pellet was resuspended in 5 volumes $(\mathrm{v} / \mathrm{w})$ of ice-cold $50 \mathrm{mM}$ Tris/ $\mathrm{HCl}$ ( $\mathrm{pH} 7.4$ ) buffer containing $0.32 \mathrm{M}$ sucrose and stored in aliquots in liquid nitrogen. Prior to the experiment, aliquots were thawed and centrifuged at 20,000 $\mathrm{g}$ for $25 \mathrm{~min}$ and the pellets were resuspended in $50 \mathrm{mM}$ Tris/ $\mathrm{HCl}$ ( $\mathrm{pH} 7.4$ ) containing $1 \%(\mathrm{w} / \mathrm{v}) \mathrm{BSA}$, homogenized with a Dounce followed by the determination of the protein content by the method of Bradford (Bradford, 1976). The membrane suspensions were immediately used either in $\left[{ }^{35} \mathrm{~S}\right] \mathrm{GTP} \gamma \mathrm{S}$ functional assays or in radioligand binding experiments. CD1 mouse brain homogenates required for the competition and $\left.{ }^{35} \mathrm{~S}\right] \mathrm{GTP} \gamma \mathrm{S}$ binding experiments on CB1 knockout samples were kind gifts of Dr. Sándor Benyhe and Dr. Ferenc Zádor (Biological Research Center, Institute of Biochemistry) and were processed as described above. The CB1 knockout mouse strain was generated as described by Ledent and co-workers (Ledent et al., 1999).

\subsection{Receptor binding assays}

All binding experiments were carried out at $37^{\circ} \mathrm{C}$ in plastic tubes in a final volume of $1 \mathrm{~mL} 50 \mathrm{mM}$ Tris/ $\mathrm{HCl}, 3 \mathrm{mM} \mathrm{MgCl}$ working buffer $(\mathrm{pH}$ : 7.4) that contained $0.2-0.5 \mathrm{mg} / \mathrm{mL}$ membrane protein and $1 \%(\mathrm{w} / \mathrm{v}) \mathrm{BSA}$ to reduce non-specific binding. Incubation mixtures were filtered through Whatman GF/B glass fiber filters with a Brandel Cell Harvester (serial\#: 2620) and filters were pre-soaked and washed three times with $50 \mathrm{mM}$ Tris/ $\mathrm{HCl}(\mathrm{pH}$ 7.4) washing buffer that contained $0.1 \%(\mathrm{w} / \mathrm{v})$ BSA. Association kinetic curves were established by coincubating $\left.2 \mathrm{nM}{ }^{3} \mathrm{H}\right] \mathrm{Hp}(1-7)$ with the membrane preparation in the absence (total binding) or presence (non-specific binding) of $10 \mu \mathrm{M}$ $\mathrm{Hp}(1-7)$. Dissociation kinetic curves were determined after preincubation of the membrane homogenate with $2 \mathrm{nM}$ radioligand for $30 \mathrm{~min}$ in the presence of $1 \mathrm{mM}$ EGTA, $1 \mathrm{mM}$ EDTA, $2 \mathrm{mM}$ PMSF and $0.1 \mathrm{mM}$ bestatin to reach equilibrium, and then dissociation was initiated by the addition of $10 \mu \mathrm{M} \mathrm{Hp}(1-7)$ after the indicated periods of time. The equilibrium dissociation constant $\left(K_{d}\right)$ and the maximum number of binding sites $\left(\mathrm{B}_{\max }\right)$ were determined by saturation binding experiments performed with increasing concentrations of $\left[{ }^{3} \mathrm{H}\right] \mathrm{Hp}(1-7)$ (0.1-16/20 nM) in the absence (total binding) or presence (non-specific binding) of $10 \mu \mathrm{M} \mathrm{Hp}(1-7)$. Competition binding studies were performed by incubating the brain membrane homogenates of rat or CB1 knockout mouse with $2 \mathrm{nM}\left[{ }^{3} \mathrm{H}\right] \mathrm{Hp}(1-7)$ in the presence of increasing concentrations of various competing ligands $\left(10^{-5}\right.$ to $\left.10^{-12} \mathrm{M}\right)$ for $30 \mathrm{~min}$ at $37^{\circ} \mathrm{C}$. Non-specific binding was determined by the addition of $10 \mu \mathrm{M} \mathrm{Hp}(1-7)$. The samples were incubated in a shaking water bath and reactions were stopped by the addition of ice-cold washing buffer followed by fast filtration. The filters were immersed into an Ultima Gold XR scintillation cocktail and radioactivity was measured with a Packard Tri-Carb 2100 TR liquid scintillation analyzer.

\subsection{Ligand stimulated $\left[{ }^{35}\right.$ SJGTP $\gamma$ s binding assay}

Rat brain membranes (30 $\mu$ g protein/tube) were incubated with $0.05 \mathrm{nM}\left[{ }^{35} \mathrm{~S}\right]$ GTPS (PerkinElmer) and with $10^{-10}$ to $10^{-6} \mathrm{M}$ unlabeled ligands in the presence of $30 \mu \mathrm{M} \mathrm{GDP}, 100 \mathrm{mM} \mathrm{NaCl}, 3 \mathrm{mM} \mathrm{MgCl}$ and $1 \mathrm{mM}$ EGTA in $50 \mathrm{mM}$ Tris/ $\mathrm{HCl}$ buffer ( $\mathrm{pH} \mathrm{7.4)}$ ) for $60 \mathrm{~min}$ at $30{ }^{\circ} \mathrm{C}$. Basal $\left[{ }^{35} \mathrm{~S}\right] \mathrm{GTP} \gamma \mathrm{S}$ binding was measured in the absence of ligands and was set as $100 \%$. Nonspecific binding was determined by the addition of $10 \mu \mathrm{M}$ unlabeled GTP $\gamma \mathrm{S}$ and subtracted from total binding. Incubation, filtration and radioactivity measurement were carried out as described above.

\section{Data analysis}

Results of the kinetic experiments are reported as means \pm S.E.M. of at least three independent experiments each performed in duplicate.
Non-linear regression analyses of the association and dissociation curves and the direct saturation isotherms were performed to obtain the observed association rate constant $\left(\mathrm{k}_{\mathrm{obs}}\right)$, the dissociation rate constant $\left(\mathrm{k}_{\mathrm{d}}\right)$, the equilibrium dissociation constant $\left(\mathrm{K}_{\mathrm{d}}\right)$ and the receptor density $\left(\mathrm{B}_{\max }\right)$. In competition binding studies, the inhibitory constants $\left(\mathrm{K}_{\mathrm{i}}\right)$ were calculated from the inflection points of the displacement curves using non-linear least-square curve fitting and the ChengPrusoff equation. All data and curves were analyzed by GraphPad Prism 4.0 (San Diego, CA, USA). In $\left[{ }^{35} \mathrm{~S}\right] \mathrm{GTP} \gamma \mathrm{S}$ binding studies, data were expressed as the percentage stimulation of the specific $\left[{ }^{35} \mathrm{~S}\right] \mathrm{GTP} \gamma \mathrm{S}$ binding over the basal activity and are given as means \pm S.E.M. Each experiment was performed in triplicate and analyzed with sigmoid dose-response curve fitting to obtain potency $\left(\mathrm{EC}_{50}\right)$ and efficacy $\left(E_{\max }\right)$ values. Statistical comparison was done by analysis of variance (one-way ANOVA) followed by the Bonferroni multiple comparison test of GraphPad Prism 4.0 (San Diego, CA, USA), P $<0.05$ was chosen to indicate significant differences.

\section{Results}

\subsection{Association and dissociation binding studies of $\left[{ }^{3} \mathrm{H}\right] \mathrm{Hp}(1-7)$}

Association and dissociation binding assays were performed to characterize the interaction of $\left[{ }^{3} \mathrm{H}\right] \mathrm{Hp}(1-7)$ with membrane receptors using rat brain membrane homogenate that is known to contain CB1 receptors abundantly. Association binding experiments carried out in the presence of $2 \mathrm{nM}\left[{ }^{3} \mathrm{H}\right] \mathrm{Hp}(1-7)$ and a protein concentration of $0.45 \mathrm{mg} / \mathrm{mL}$ revealed specific binding of $\left[{ }^{3} \mathrm{H}\right] \mathrm{Hp}(1-7)$ to rat brain membranes at $37^{\circ} \mathrm{C}$. At this temperature, specific binding reached steady-
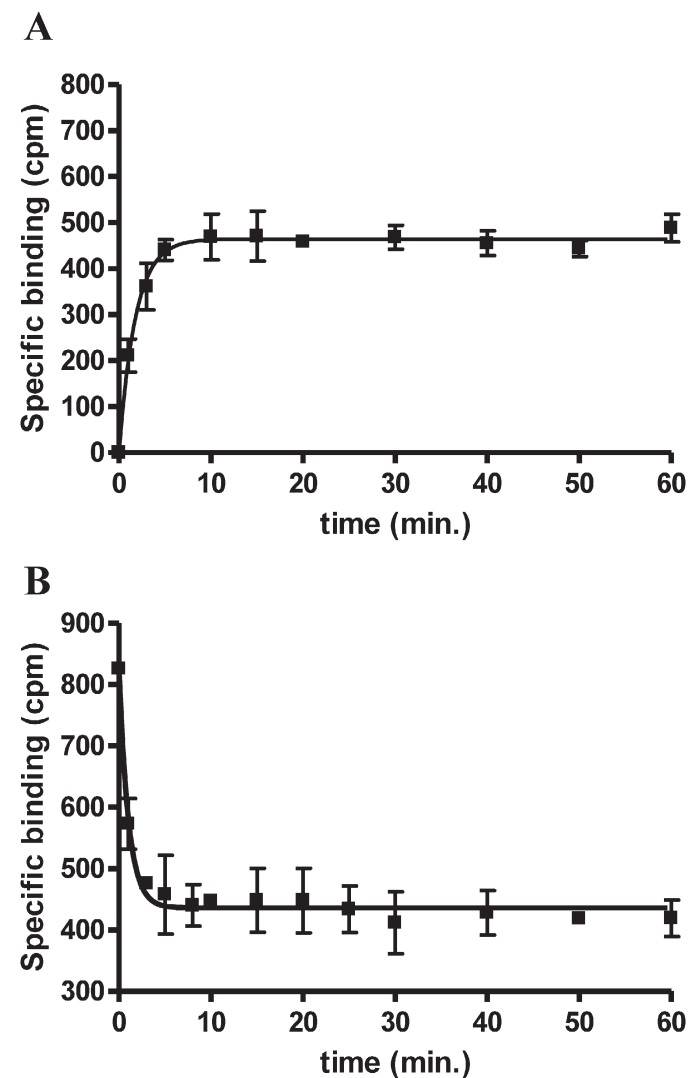

Fig. 1. (A.) Association time course of $\left[{ }^{3} \mathrm{H}\right] \mathrm{Hp}(1-7)$ binding at $37{ }^{\circ} \mathrm{C} .2 \mathrm{nM}\left[{ }^{3} \mathrm{H}\right] \mathrm{Hp}(1-7)$ was incubated with rat brain membrane for various time in the absence or presence of $10 \mu \mathrm{M} \mathrm{Hp}(1-7)$ to assess specific binding ( $\mathbf{\square})$. (B.) Dissociation time course of $\left[{ }^{3} \mathrm{H}\right] \mathrm{Hp}(1-7)$ binding at $37{ }^{\circ} \mathrm{C} .2 \mathrm{nM}\left[{ }^{3} \mathrm{H}\right] \mathrm{Hp}(1-7)$ was incubated with rat brain membrane for $30 \mathrm{~min}$, then dissociation was initiated by the addition of $10 \mu \mathrm{M} \mathrm{Hp}(1-7)$ after different time points. Data are means \pm S.E.M of at least 5 independent experiments. 
Table 1

Kinetic parameters for $\left[{ }^{3} \mathrm{H}\right] \mathrm{Hp}(1-7)$ in rat brain membrane homogenate.

\begin{tabular}{lc}
\hline Kinetic parameters & \\
\hline $\mathrm{K}_{\mathrm{obs}}\left(\mathrm{min}^{-1}\right)$ & $1.08 \pm 0.12$ \\
$\mathrm{~K}_{\mathrm{a}}\left(\mathrm{nM}^{-1} \min ^{-1}\right)$ & $0.119 \pm 0.001$ \\
$\mathrm{~K}_{\mathrm{d}}\left(\mathrm{min}^{-1}\right)$ & $0.842 \pm 0.150$ \\
$\mathrm{~K}_{\mathrm{d}}(\mathrm{nM})$ & $7.2 \pm 1.4$ \\
\hline
\end{tabular}

$\mathrm{k}_{\text {obs }}$ is the observed pseudo-first order rate constant, $\mathrm{k}_{\mathrm{d}}$ is the dissociation rate constant, $\mathrm{k}_{\mathrm{a}}$ is the association rate constant calculated according to the following equation: $\mathrm{k}_{\mathrm{a}}=\left(\mathrm{k}_{\mathrm{obs}}-\mathrm{k}_{\mathrm{d}}\right) /$ [radioligand]. $\mathrm{K}_{d}$ was calculated as follows: $\mathrm{K}_{\mathrm{d}}=\mathrm{k}_{\mathrm{d}} / \mathrm{k}_{\mathrm{a}}$. Data are calculated from the average \pm S.E.M of at least 3 independent experiments

state in $5 \mathrm{~min}$ (Fig. 1A.) that remained stable up to $60 \mathrm{~min}$. The specific binding was $50-60 \%$ of the total binding at $2 \mathrm{nM}$ radioligand concentration under equilibrium conditions. Table 1 summarizes the calculated equilibrium binding parameters. In the dissociation experiments, rat brain membranes were incubated with $2 \mathrm{nM}\left[{ }^{3} \mathrm{H}\right] \mathrm{Hp}(1-7)$ at $37{ }^{\circ} \mathrm{C}$ for $30 \mathrm{~min}$ and dissociation of the ligand-receptor complex was initiated by the addition of $10 \mu \mathrm{M} \mathrm{Hp}(1-7)$ at different incubation time-points. Dissociation proceeded with a monophasic kinetics (Fig. 1B.) providing a dissociation rate constant $\left(k_{d}\right)$ of $0.842 \pm 0.150 \mathrm{~min}^{-1}$. It was found that $55 \%$ of the radioligand dissociated from the membranes. The kinetically derived equilibrium dissociation constant $\left(\mathrm{K}_{\mathrm{d}}\right)$ calculated from the association and dissociation experiments was assessed to be $7.2 \pm$ $1.2 \mathrm{nM}$ under our experimental conditions.

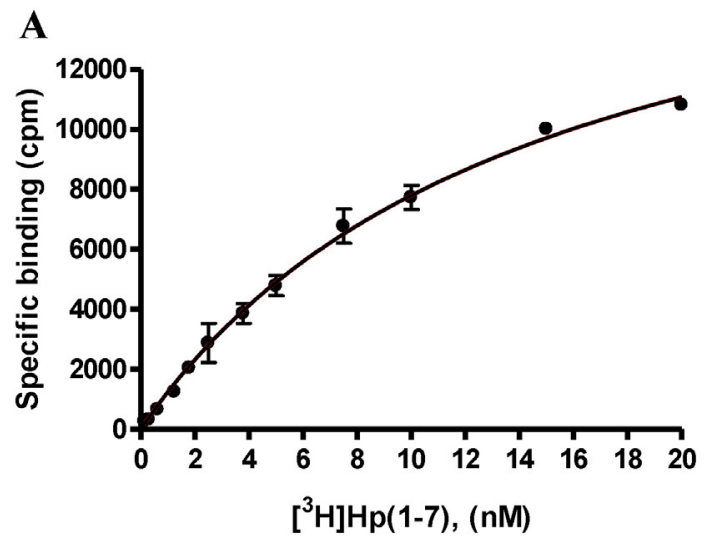

B

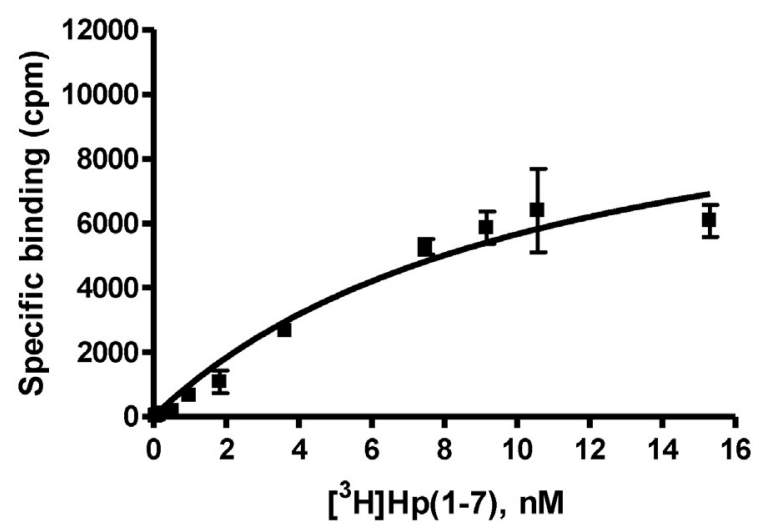

Fig. 2. Saturation isotherms of $\left[{ }^{3} \mathrm{H}\right] \mathrm{Hp}(1-7)$. Increasing concentrations of the radioligand were incubated with membrane homogenates of rat brain (A.) or CB1 knockout mouse brain (B.) in the absence or presence of $10 \mu \mathrm{M} \mathrm{Hp}(1-7)$. Only specific binding data are presented as means \pm S.E.M of at least 3 independent experiments.

\subsection{Saturation binding studies of $\left[{ }^{3} \mathrm{H}\right] \mathrm{Hp}(1-7)$}

Saturation radioligand binding experiments were carried out in brain homogenates of rat and CB1 knockout mouse in the presence of increasing radioligand concentrations for $30 \mathrm{~min}$. The specific binding of $\left[{ }^{3} \mathrm{H}\right] \mathrm{Hp}(1-7)$ was found to be saturable and of high affinity (nanomolar range) in both tissue homogenates (Fig. 2A. and B.). Single-site bindings were calculated for both saturation curves by non-linear fitting of the specific binding data points that resulted in dissociation equilibrium constants $\left(K_{d}\right)$ of $14.5 \pm 3.2 \mathrm{nM}$ and $10.8 \pm$ $1.8 \mathrm{nM}$ in rat and in CB1 knockout mouse brain membrane, respectively. Furthermore, high receptor densities $\left(B_{\max }=830 \pm 120\right.$ and $990 \pm$ $145 \mathrm{fmol} / \mathrm{mg}$ protein in rat and in CB1 knockout mouse brain membranes, respectively) were observed (Table 2 ). These $K_{d}$ and $B_{\max }$ values suggested that the target receptor for the $\mathrm{Hp}(1-7)$ peptide was present in both tissue homogenates and indicated the specific interaction of $\left[{ }^{3} \mathrm{H}\right] \mathrm{Hp}(1-7)$ with a highly abundant receptor protein.

\subsection{Competitive binding studies of $\left.{ }^{3} \mathrm{H}\right] \mathrm{Hp}(1-7)$}

The saturation binding experiments indicated that the binding site of $\left[{ }^{3} \mathrm{H}\right] \mathrm{Hp}(1-7)$ might be different from the $\mathrm{CB} 1$ receptor, $\left(\left[{ }^{3} \mathrm{H}\right] \mathrm{Hp}(1-7)\right.$ also displayed saturable binding in a CB1 knockout brain homogenate) therefore we further characterized the labeled $\mathrm{Hp}(1-7)$ in competition receptor binding assays in rat brain membrane homogenate. First different non-peptidic cannabinoid agonists and inverse agonists were used as competitor ligands (Fig. 3).

It was found that neither the non-selective cannabinoid full agonist JWH-018, the CB1 receptor inverse agonist AM251 nor the CB1 receptor inverse agonist rimonabant could displace the bound radioligand in rat brain membranes. Only the unlabeled $\mathrm{Hp}(1-7)$ was able to compete with its tritium labeled analog, with an apparently high inhibitory constant of $103 \pm 23 \mathrm{nM}$. In contrast, a $K_{d}$ value of $14.5 \pm 3.2$ was obtained by the analysis of the kinetic curves. Next, competition binding experiments were performed to investigate the ability of hemopressins $\mathrm{Hp}(1-7), \mathrm{Hp}(1-9)$ and $\mathrm{RVD}-\mathrm{Hp}(1-9)$ to inhibit the binding of $\left[{ }^{3} \mathrm{H}\right] \mathrm{Hp}(1-7)$ in rat brain membrane homogenate (Fig. 4A.).

These hemopressins could displace $\left[{ }^{3} \mathrm{H}\right] \mathrm{Hp}(1-7)$ from the binding site with different inhibitory constants (Table 3 ). The parent $\mathrm{Hp}(1-7)$ displayed the highest affinity $\left(K_{\mathrm{i}}=111 \pm 14 \mathrm{nM}\right)$ to the binding site. The $\mathrm{Hp}(1-9)$ peptide provided a slightly higher inhibitory constant $\left(\mathrm{K}_{\mathrm{i}}=184 \pm 28 \mathrm{nM}\right)$ but still within the same order of magnitude. These data indicated that $\mathrm{Hp}(1-7)$ and $\mathrm{Hp}(1-9)$ might bind to the same site or conformation of a receptor protein, however both $\mathrm{Hp}(1-9)$ and $\mathrm{Hp}(1-7)$ might prefer a receptor conformation or binding site different from those of the non-peptidic cannabinoid agonists. In contrast, the RVD-extended hemopressin (pepcan 12) displayed the lowest binding affinity $\left(\mathrm{K}_{\mathrm{i}}=1940 \pm 121 \mathrm{nM}\right)$ to the $\left[{ }^{3} \mathrm{H}\right] \mathrm{Hp}(1-7)$ labeled sites.

The findings of the saturation and competition binding studies indicated the existence of a non-cannabinoid binding site or a receptor protein. In order to provide further evidences for this assumption, the ability of cannabinoid ligands and hemopressins to compete with $\left[{ }^{3} \mathrm{H}\right] \mathrm{Hp}(1-7)$ in CB1 knockout mouse brain membrane homogenate was investigated (Fig. 4B.). It was found that $\mathrm{Hp}(1-7)$ displayed the lowest inhibitory constant $\left(\mathrm{K}_{\mathrm{i}}=94 \pm 25 \mathrm{nM}\right)$, and this affinity was

Table 2

Equilibrium binding data of $\left[{ }^{3} \mathrm{H}\right] \mathrm{Hp}(1-7)$

\begin{tabular}{lll}
\hline Tissue & $\mathrm{K}_{\mathrm{d}}(\mathrm{nM})$ & $\mathrm{B}_{\max }(\mathrm{fmol} / \mathrm{mg})$ \\
\hline Rat brain membrane & $11.8 \pm 2.2$ & $830 \pm 120$ \\
CB1-KO mouse brain membrane & $12.8 \pm 1.8$ & $990 \pm 145$ \\
\hline
\end{tabular}

Dissociation equilibrium constants $\left(K_{d}\right)$ and receptor densities $\left(B_{\max }\right)$ were calculated by fitting of the saturation curves measured in brain membrane homogenates of wild-type rat or CB1 knockout mouse in the absence or presence of $10 \mu \mathrm{M} \mathrm{Hp}(1-7)$. Data are means \pm S.E.M of at least 3 independent experiments. 


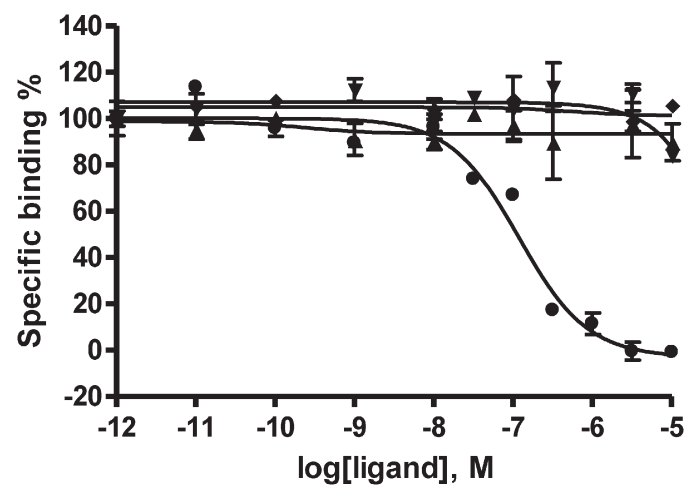

Fig. 3. Competitive binding curves of $\left[{ }^{3} \mathrm{H}\right] \mathrm{Hp}(1-7)$. Rat brain membrane was incubated with $2 \mathrm{nM}\left[{ }^{3} \mathrm{H}\right] \mathrm{Hp}(1-7)$ in the presence of $10^{-12}-10^{-5} \mathrm{M}$ of $\mathrm{Hp}(1-7)(\bullet)$, rimonabant $(\boldsymbol{\Delta})$, AM251 ( $)$ or JWH-018 ( ) for $30 \mathrm{~min}$ at $37{ }^{\circ} \mathrm{C}$. Non-specific binding was measured in the presence of $10 \mu \mathrm{M} \mathrm{Hp}(1-7)$, data are means \pm S.E.M., $\mathrm{n}=3$.

close to that detected in rat brain membrane homogenate (Table 3.). The similar affinity values obtained for $\mathrm{Hp}(1-7)$ in the homologue displacement studies both in rat and CB1 knockout mouse brain membrane homogenates strongly suggest that the receptor of the $\mathrm{Hp}(1-7)$ peptide has to be present in both tissue samples. Furthermore, the higher differences in inhibitory constants $\left(K_{\mathrm{i}}=184 \pm 28 \mathrm{nM}\right.$ vs. $401 \pm 78 \mathrm{nM})$ for the $\mathrm{Hp}(1-9)$ peptide in rat and CB1 knockout mouse brain homogenates may refer to binding to different regions of the same receptor in the two species or binding to the same region of the receptors with sequence heterogeneity in the two mammalian species. Similarly to the findings in whole rat brain membrane homogenate,
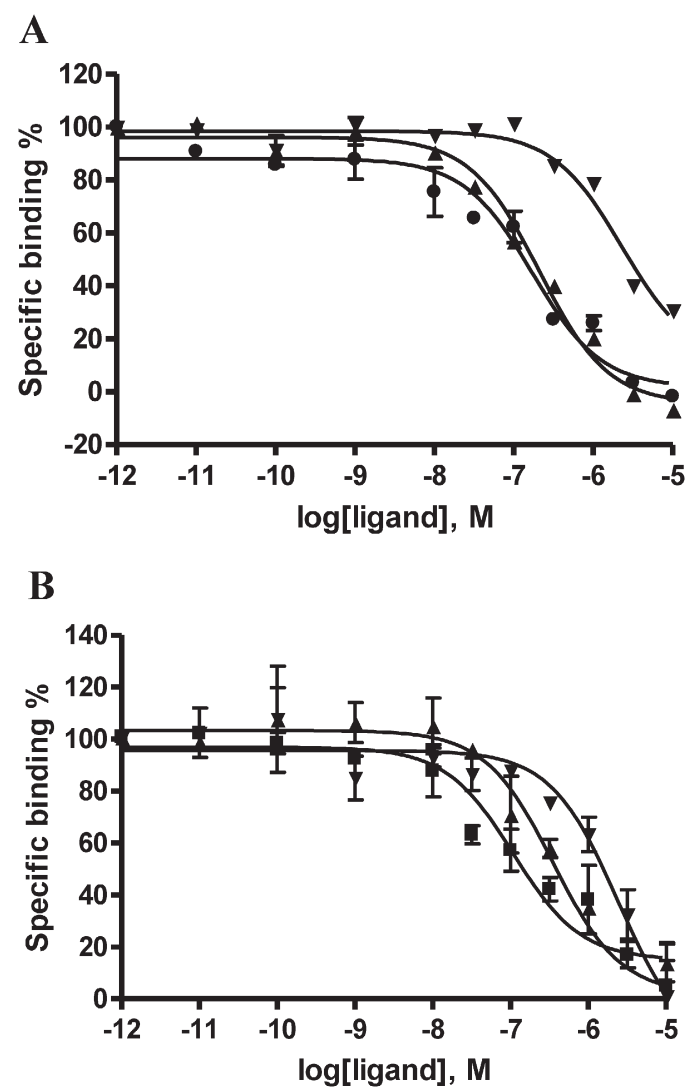

Fig. 4. Competitive binding curves of $\left[{ }^{3} \mathrm{H}\right] \mathrm{Hp}(1-7)$ by various hemopressins. Brain membranes of rat (A.) or CB1 knockout mouse (B.) were co-incubated with $2 \mathrm{nM}$ $\left[{ }^{3} \mathrm{H}\right] \mathrm{Hp}(1-7)$ in the presence of $10^{-12}-10^{-5} \mathrm{M}$ of $\mathrm{Hp}(1-7)(\bullet), \mathrm{Hp}(1-9)(\boldsymbol{\Delta})$ or RVD$\mathrm{Hp}(1-9)(\boldsymbol{\nabla})$. Non-specific binding was measured in the presence of $10 \mu \mathrm{M} \mathrm{Hp}(1-7)$. Data are means \pm S.E.M., $\mathrm{n}=3$.
Table 3

Inhibitory constants $\left(\mathrm{K}_{\mathrm{i}}\right)$ of hemopressins against $\left[{ }^{3} \mathrm{H}\right] \mathrm{Hp}(1-7)$ in rat brain membrane homogenate.

\begin{tabular}{lc}
\hline Ligands & Inhibitory constant $\left(\mathrm{K}_{\mathrm{i}}\right), \mathrm{nM}$ \\
\hline $\mathrm{Hp}(1-7)$ & $111 \pm 14$ \\
$\mathrm{Hp}(1-9)$ & $184 \pm 28$ \\
$\operatorname{RVD}-\mathrm{Hp}(1-9)$ & $1940 \pm 121$ \\
$\mathrm{Hp}(1-7)$ & $94 \pm 25$ \\
$\mathrm{Hp}(1-9)$ & $401 \pm 78$ \\
$\operatorname{RVD}-\mathrm{Hp}(1-9)$ & $3208 \pm 396$ \\
\hline
\end{tabular}

Hemopressins were co-incubated with $\left[{ }^{3} \mathrm{H}\right] \mathrm{Hp}(1-7)$ in brain homogenate of rat or $\mathrm{CB} 1$ knockout mouse. Data are means \pm S.E.M, $\mathrm{n}=3$.

the RVD-Hp(1-9) peptide showed marginal binding affinity $\left(K_{i}=\right.$ $3208 \pm 396 \mathrm{nM})$ to the $\left[{ }^{3} \mathrm{H}\right] \mathrm{Hp}(1-7)$ labeled sites.

\subsection{Ligand stimulated $\Gamma^{35}$ SJGTP $\gamma$ s binding studies}

Since hemopressins were reported to be the agonist ligands of the CB1 receptor, we were curious about how $\mathrm{Hp}(1-7)$ and $\mathrm{Hp}(1-9)$ activate $\mathrm{G}$-proteins. The $\mathrm{CB} 1$ receptor full agonist JWH-018 and the inverse agonist rimonabant were applied as positive controls to validate the conditions of the ligand stimulated $\left.{ }^{35} \mathrm{~S}\right] \mathrm{GTP} \gamma \mathrm{S}$ binding assay in rat brain membranes. JWH-018 stimulated $\left[{ }^{35} \mathrm{~S}\right] \mathrm{GTP} \gamma \mathrm{S}$ binding with the
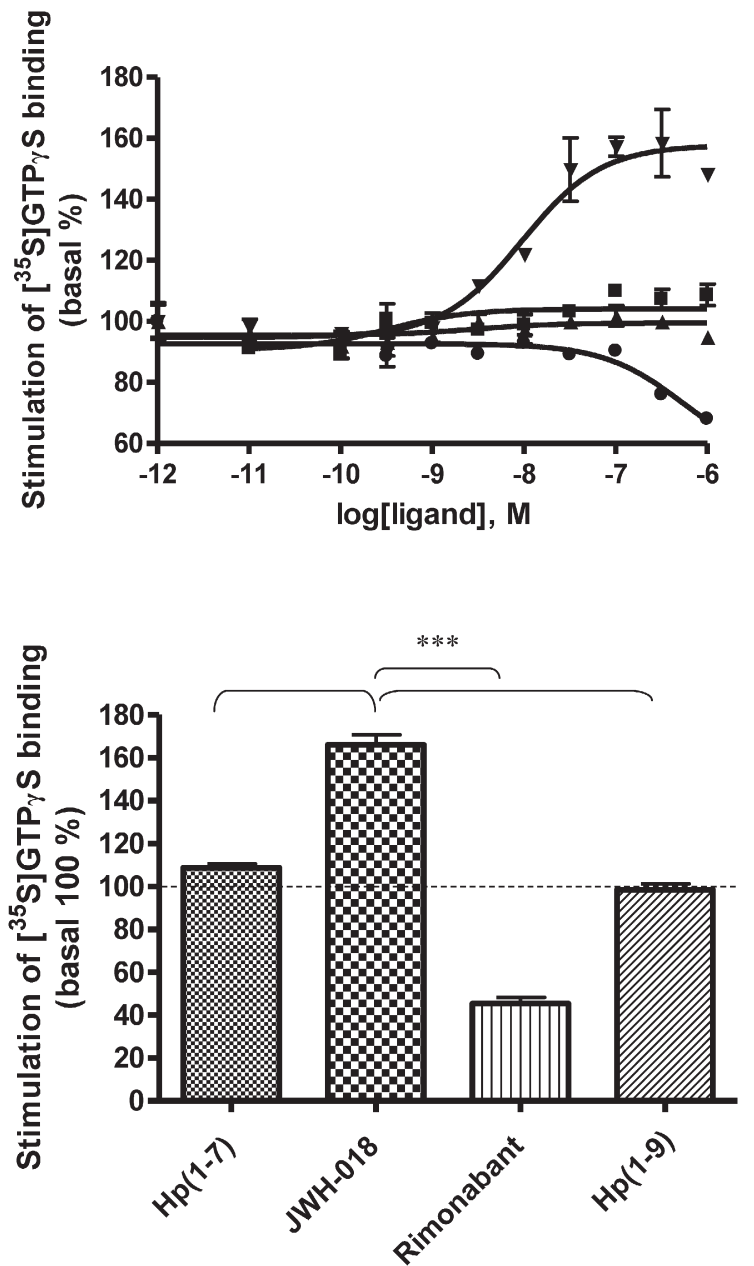

Fig. 5. $\left[{ }^{35} \mathrm{~S}\right] \mathrm{GTP} \gamma \mathrm{S}$ binding stimulated by $\mathrm{Hp}(1-7), \mathrm{Hp}(1-9)$ and cannabinoid ligands in rat brain membrane homogenate. JWH-018 and rimonabant were used as positive controls. Rat brain membranes were incubated with $0.05 \mathrm{nM}\left[{ }^{35} \mathrm{~S}\right] \mathrm{GTP} \gamma \mathrm{S}$ in the presence of

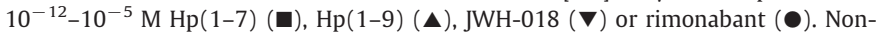
specific binding was measured with $10 \mu \mathrm{M}$ GTP $\gamma \mathrm{S}$. Data are expressed as means \pm S.E.M., $\mathrm{n}=3$. Significant differences were defined as $\mathrm{P}<0.05$. 
highest efficacy $\left(\mathrm{E}_{\max }=165 \pm 25 \%\right)$ and lowest potency $\left(\mathrm{EC}_{50}=9.5 \pm\right.$ $1.2 \mathrm{nM}$ ) in good agreement with literature data (Atwood et al., 2010) (Fig. 5.). Rimonabant also behaved as described in the literature (Zador et al., 2014). The $\mathrm{Hp}(1-7)$ peptide displayed low potency $\left(\mathrm{EC}_{50}=21 \pm 1.5 \mathrm{nM}\right)$ and marginal stimulatory activity $\left(\mathrm{E}_{\max }=\right.$ $112 \pm 8 \%$ ) as compared to the well-known non-peptidic cannabinoids (Fig. 5 and Table 4). $\mathrm{Hp}(1-9)$ also showed low potency $\left(\mathrm{EC}_{50}=29 \pm\right.$ $3.5 \mathrm{nM})$, but did not activate $\left[{ }^{35} \mathrm{~S}\right] \mathrm{GTP} \gamma \mathrm{S}$ binding $\left(\mathrm{E}_{\max }=104 \pm 7 \%\right)$. Next, $\mathrm{Hp}(1-7)$ and $\mathrm{Hp}(1-9)$ were tested in $\left.{ }^{35} \mathrm{~S}\right] \mathrm{GTP} \gamma \mathrm{S}$ binding assays using membranes prepared from the brain of CB1 knockout mice. We used the opioid full agonist DAMGO as a positive control to compare $\left.{ }^{35} \mathrm{~S}\right]$ GTP $\gamma S$ activation and to test the validity of our experimental model (Fig. 6 and Table 5).

The agonist control compound DAMGO exhibited low potency $\left(\mathrm{EC}_{50}=177 \pm 21 \mathrm{nM}\right)$ and significant stimulation $\left(\mathrm{E}_{\max }=167 \pm\right.$ $20 \%$ ) of $\left[{ }^{35} \mathrm{~S}\right] \mathrm{GTP} \gamma \mathrm{S}$ binding as compared to $\mathrm{Hp}(1-7)$ and $\mathrm{Hp}(1-9)$. The $\mathrm{Hp}(1-7)$ peptide demonstrated a higher potency value $\left(\mathrm{EC}_{50}=\right.$ $655 \pm 98 \mathrm{nM}$ ), in comparison with the potency obtained in rat brain membrane homogenate. However, $\mathrm{Hp}(1-7)$ displayed very similar stimulatory effects in both wild type rat brain and CB1 knockout mouse brain homogenates $\left(\mathrm{E}_{\max }=112 \pm 12\right.$ and $117 \pm 18 \%$ ). Similarly to the competitive displacement studies this finding suggests that the ligand activates a G-protein or binds to a protein through the same binding site or receptor protein(s) that is/are present in both types of tissues. Consequently, its main target protein cannot be the CB1 receptor because it is not supposed to be present in the brain membrane preparation of $\mathrm{CB} 1$ knockout mice. The $\mathrm{Hp}(1-9)$ peptide showed higher potency $\left(\mathrm{EC}_{50}=65 \pm 12 \mathrm{nM}\right)$, but a stimulatory effect $\left(\mathrm{E}_{\max }=\right.$ $111 \pm 17 \%$ ) roughly equivalent with that of the $\mathrm{Hp}(1-7)$ peptide. This difference in the potency value may reflect different binding mode or interaction of the $\mathrm{Hp}(1-9)$ peptide with its binding partner.

\section{Discussion}

The endocannabinoid system is involved in the regulation of many physiological and pathological processes, therefore, a better understanding of its function is of high importance (Pacher et al., 2006). The recently discovered $\alpha$-hemoglobin derived hemopressins have been postulated to be negative allosteric modulators and endogenous agonist ligands of the CB1 receptors. These peptides have been demonstrated to possess in vitro and in vivo pharmacological potencies similar to those of the prototypic endogenous and synthetic cannabinoid ligands, but with less side-effects (Dale et al., 2005; Heimann et al., 2007; Gomes et al., 2009; Bomar and Galande, 2012). Accordingly, hemopressins have appeared to be excellent lead compounds for the development of peptidic research tools for the investigation of the endocannabinoid system. Their reported pharmacological characteristics have prompted us to prepare a radiolabeled peptide ligand that acts on the CB1 receptor and thus, enables the direct investigation of the endocannabinoid system and the binding properties of new synthetic CB1 receptor ligands.

The $\mathrm{Hp}(1-9)$ peptide and its extended or truncated derivatives were demonstrated to be orally active and to exert antinociceptive effects that were apparently mediated by the CB1 receptors (Bomar and Galande, 2012). The physiological activity upon oral administration suggests that these peptides are at least partially resistant to proteolysis,

\section{Table 4}

Summary of the results of $\left[{ }^{35} \mathrm{~S}\right] \mathrm{GTP} \gamma \mathrm{S}$ functional binding assays in rat brain membrane preparation.

\begin{tabular}{lll}
\hline Ligands & $\mathrm{EC}_{50}(\mathrm{nM})$ & $\mathrm{E}_{\max }(\%)$ \\
\hline $\mathrm{Hp}(1-7)$ & $21 \pm 1.5$ & $112 \pm 8$ \\
$\mathrm{JWH}-018$ & $9.5 \pm 1.2$ & $165 \pm 25$ \\
$\mathrm{Hp}(1-9)$ & $29 \pm 3.5$ & $104 \pm 7$ \\
Rimonabant & $539 \pm 65$ & $46 \pm 7$ \\
\hline
\end{tabular}

Nonspecific binding was determined by the addition of $10 \mu \mathrm{M}$ unlabeled GTP $\gamma$ S. Data are means \pm S.E.M, $\mathrm{n}=3$, each performed in triplicate.
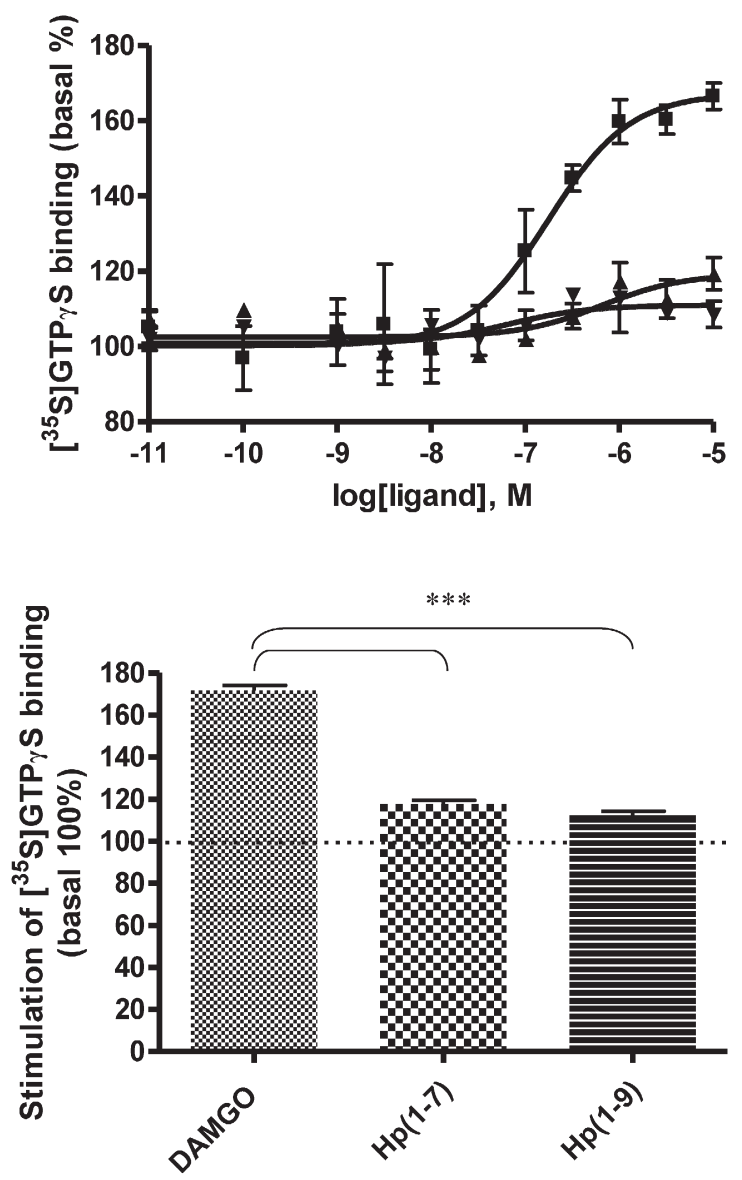

Fig. 6. $\left[{ }^{35} \mathrm{~S}\right] \mathrm{GTP} \gamma \mathrm{S}$ binding stimulated by DAMGO, $\mathrm{Hp}(1-7)$ and $\mathrm{Hp}(1-9)$ in CB1 knockout mouse brain membrane homogenate. Mouse brain membranes were incubated with $0.05 \mathrm{nM}\left[{ }^{35} \mathrm{~S}\right] \mathrm{GTP} \gamma \mathrm{S}$ in the presence of $10^{-12}-10^{-5} \mathrm{M}$ DAMGO ( $\left.\boldsymbol{\square}\right), \mathrm{Hp}(1-7)(\boldsymbol{\Delta})$ or $\mathrm{Hp}(1-9)(\boldsymbol{\nabla})$. Non-specific binding was measured in the presence of $10 \mu \mathrm{M}$ GTP $\gamma \mathrm{S}$. Data are means \pm S.E.M., $\mathrm{n}=3$.

and also that they may be able to cross the blood-brain barrier. Due to these favorable characteristics and to the fact that the truncated $\mathrm{Hp}(1-7)$ peptide was also found to be as potent as $\mathrm{Hp}(1-9)$ in in vitro and in vivo studies (Heimann et al., 2007), $\mathrm{Hp}(1-7)$ was chosen for radiolabeling without any structural modification.

The tritium labeled $\mathrm{Hp}(1-7)$ was investigated in various radioligand binding assays to characterize the interaction of $\mathrm{Hp}(1-7)$ and $\mathrm{CB}$ receptors. Data analysis of receptor binding kinetics of $\left[{ }^{3} \mathrm{H}\right] \mathrm{Hp}(1-7)$ showed that the radioligand reaches equilibrium and steady-state very fast under the experimental conditions. Saturation binding experiments revealed single-site binding and very high receptor densities in both wild type rat brain membrane and CB1 knockout mouse brain membrane homogenates. In displacement studies, the radioligand was not able to compete with the most commonly used CB1 receptor agonist/inverse agonist cannabinoid ligands. However, we found competition with $\mathrm{Hp}(1-9)$ in both types of brain homogenates which suggests that both $\mathrm{Hp}(1-7)$ and $\mathrm{Hp}(1-9)$ may be able to bind to the same receptor binding pocket or allosteric site. This result is contradictory because the CB1

Table 5

Summary of the results of $\left[{ }^{35} \mathrm{~S}\right] \mathrm{GTP} \gamma \mathrm{S}$ functional binding assay in $\mathrm{CB} 1$ knockout mouse brain membrane preparation.

\begin{tabular}{lll}
\hline Ligands & $\mathrm{EC}_{50}(\mathrm{nM})$ & $\mathrm{E}_{\max }(\%)$ \\
\hline DAMGO & $177 \pm 21$ & $167 \pm 20$ \\
$\mathrm{Hp}(1-7)$ & $655 \pm 98$ & $117 \pm 18$ \\
$\mathrm{Hp}(1-9)$ & $65 \pm 12$ & $111 \pm 17$ \\
\hline
\end{tabular}

Nonspecific binding was determined by the addition of $10 \mu \mathrm{M}$ unlabeled GTP $\gamma$ S. Data are means \pm S.E.M, $n=3$, each performed in triplicate. 
knockout mouse brain homogenate is not supposed to contain CB1 receptors. Nonetheless, the presence of allosteric binding site on CB1 receptors for hemopressins has been demonstrated (Bauer et al., 2012, Straiker et al., 2015).

More than 400 different GPCRs have been shown to be encoded in the human genome. Many of them, such as the muscarinic acetylcholine, adenosine, $\alpha$-adrenergic, bombesin, melatonin, melanocortin, neurotensin, neuromedin, orexin, galanin, opioid, serotonin and tachykinin receptors have been reported to mediate either hypotensive, antinociceptive and/or antihyperalgesic effects through inhibitory or stimulatory pathways (Stone and Molliver, 2009). Though, the abundance of these mainly neuropeptide receptors is usually much lower than that observed for the CB1 in the brain, these receptors may serve as specific or non-specific binding partners for $\mathrm{Hp}(1-7)$, and can be highly expressed in mammalian brains under physiological or pathological conditions. There are many observations supporting the evidence that hemopressins may indirectly regulate the function of other GPCRs and mediate their analgesic, antihyperalgesic and hypotensive effects likely through one or more of these receptor proteins or ion channels. Indeed, a recent exciting study has pointed to the role of TRPV1, a non-selective ligand-gated cation channel that has been proven to promote central anxiogenic effects in animal model of anxiety following i.c.v. administration of $\mathrm{Hp}(1-9)$ (Fogaça et al., 2015). This effect could be blocked by the addition of a TRPV1 antagonist further demonstrating the fact that the observed effects were mediated via a CB1 receptorindependent manner. In our functional $\left[{ }^{35} \mathrm{~S}\right] \mathrm{GTP} \gamma \mathrm{S}$ binding experiments, $\mathrm{Hp}(1-7)$ and $\mathrm{Hp}(1-9)$ behaved as very weak agonists (if at all), and could not stimulate $\left[{ }^{35} \mathrm{~S}\right] \mathrm{GTP} \gamma \mathrm{S}$ binding significantly. Recently, a very similar $\left[{ }^{35} \mathrm{~S}\right] \mathrm{GTP} \gamma \mathrm{S}$ stimulatory effect was observed in competitive radioligand and $\left[{ }^{35}\right.$ S $]$ GTP $\gamma S$ binding studies (Szlavicz et al., 2015). It was found that $\mathrm{Hp}(1-7)$ and $\mathrm{Hp}(1-9)$ slightly activated G-proteins in a naloxone-sensitive manner and that the peptides directly interacted with the CB1 and MOP receptors as well. These results support our hypothesis that hemopressins can directly or indirectly interact with other G-protein coupled receptors in different in vitro model systems and emphasize the importance of the implied experimental model. The brain derived neuropeptide FF (NPFF) and its receptors are well-known modulators of the opioid system. This system was shown to interact with the CB1 receptor as well. NPFF has recently been published to modulate cannabinoid-induced antinociception after i.c.v. administration of mouse VD-hemopressin( $\alpha$ ) (an extended analog of $\mathrm{Hp}(1-9)$ ) in naive and VD-hemopressin $(\alpha)$ tolerant mice (Pan et al., 2015). In naive mice, i.c.v. injection of NPFF dose-dependently attenuated central analgesia of VD-hemopressin( $\alpha$ ). The VD-hemopressin( $\alpha$ modulating activities of NPFF and related peptides could be antagonized by NPFF receptor selective antagonists. These results indicate a direct interaction between hemopressins and the NPFF system. Galanin is another GPCR-acting neuropeptide that is widely expressed in the brain and is a common inhibitor of action potential in neurons. Hofer and co-workers have recently found co-localization and production of this neuropeptide with peptide endocannabinoids (pepcans) in specific regions of the rodent CNS (Hofer et al., 2015). They found enhanced immunostaining and co-localization of RVD-Hp(1-9) (pepcan 12) with galanin in the hippocampus and cerebral cortex, along with the anterograde axonal bundles. However, no immunolabeling could be detected in dopaminergic neurons. These findings further confirm the fact that hemopressins can widely interact with various endogenous neuropeptide systems and can co-regulate pain perception and alleviation.

Based on our direct in vitro receptor binding results and the large number of literature data, we hypothesize that hemopressins indirectly interact with the $\mathrm{CB} 1$ receptor. They more likely up-regulate the endocannabinoid production and the subsequent endocannabinoid release may be responsible for the observed analgesic effects. This assumption seems to be further supported by the study of Toniolo and co-workers (Toniolo et al., 2014a, 2014b). They found that hemopressin could inhibit monoacylglycerol-lipase activity in dorsal root ganglions and this might lead to an increase of 2-arachidonoyl-glycerol inducing analgesia. They also hypothesized that hemopressin can interact with the peripheral voltage-gated potassium channels and reduce calcium influx in a synergistic manner with the peripheral cannabinoid receptors. It was also concluded that hemopressin can induce an increase of endocannabinoid level and this would, in turn, lead to the activation of descending inhibitory pain pathways inducing analgesia. However, we cannot fully exclude the existence of allosteric binding site for hemopressins, especially based on the recent findings of Straiker and co-workers (Straiker et al., 2015). They studied positive and negative allosteric modulators of the endocannabinoid-mediated synaptic transmission in cultured hippocampal neurons. In their study, RVD-Hp(1-9) that did not apparently exhibit binding to the CB1 receptor in our system attenuated depolarization-induced suppression of excitation. Interestingly, $\mathrm{Hp}(1-9)$ was ineffective in this model of endocannabinoid signaling. These outcomes shed light on the importance of the implied model system and on variations between the potencies and interaction of endocannabinoids/pepcans with their respective receptors.

Since hemopressins have been reported to possess outstanding pharmacological properties in many in vivo models, further in-depth in vitro and in vivo studies will be necessary for the delineation of $\mathrm{Hp}(1-7)$ binding site and its pharmacological significance in mammalian species.

\section{Acknowledgment}

This work was supported by the NKTH-OTKA "Outgoing Mobility" grant (OTKA ID: Human MB08A-84459) (A.K). Financial support from the Hungarian Scientific Research Fund (K77783), from the Hungarian National Development Agency (TÁMOP 4.2.2.A-11/1/KONV-20120052) and the János Bolyai Research Scholarship of the Hungarian Academy of Sciences (Cs.T.) are acknowledged. We also thank the CB1 knock-out mouse brain homogenate and rimonabant to Dr. Sándor Benyhe and Dr. Ferenc Zádor.

\section{References}

Atwood, B.K., Huffman, J., Straiker, A., Mackie, K., 2010. JWH-018, a common constituent of "spice" herbal blends, is a potent and efficacious cannabinoid CB1 receptor agonist. Br. J. Pharmacol. 160 (3), 585-593.

Bauer, M., Chicca, A., Tamborrini, M., Eisen, D., Lerner, R., Lutz, B., Poetz, O., Pluschke, G., Gertsch, J., 2012. Identification and quantification of a new family of peptide endocannabinoids (pepcans) showing negative allosteric modulation at CB1 receptors. J. Biol. Chem. 287 (44), 36944-36967.

Begg, M., Pacher, P., Batkai, P., Osei-Hyiaman, D., Offertaler, L., Mo, F.M., Liu, J., Kunos, G., 2005. Evidence for novel cannabinoid receptor. Pharmacol. Ther. 106, 133-145.

Blais, P.A., Cote, J., Morin, J., Larouch, A., Gendron, G., Fortier, A., Regoli, D., Neugebauer, W., Gobeil Jr., F., 2005. Hypotensive effects of hemopressin and bradykinin in rabbits, rats and mice. A comparative study. Peptides 26, 8,1317-8,1322.

Bomar, M.G., Galande, A.K., 2012. Modulation of the cannabinoid receptors by hemopressin peptides. Life Sci. 92 (8-9), 520-524.

Boyd, S.T., 2006. The endocannabinoid system. Pharmacotherapy 26, 218S-221S

Bradford, M.M., 1976. A rapid and sensitive method for quantitation of microgram quantities of protein utilizing the principle of protein-dye binding. Anal. Biochem. $72,248-254$.

Dale, C.S., de Lima, Pagano R., Rioli, V., Hyslop, S., Giorgi, R., Ferro, E.S., 2005 Antinociceptive action of hemopressin in experimental hyperalgesia. Peptides 26, 431-436.

Di Marzo, V., Petrosino, S., 2007. Endocannabinoids and the regulation of their levels in health and disease. Curr. Opin. Lipidol. 18, 129-140.

Dodd, G.T., Mancini, G., Lutz, B., Luckman, S.M., 2010. The peptide hemopressin acts through CB1 cannabinoid receptors to reduce food intake in rats and mice. J. Neurosci. 30, 21,7369-21,7376.

Dodd, G.T., Worth, A.A., Hodkinson, D.J., Srivastava, R.K., Lutz, B., Williams, S.R., Luckman, S.M., 2013. Central functional response to the novel peptide cannabinoid hemopressin. Neuropharmacology 71, 27-36.

Fogaça, M.V., Sonego, A.B. Rioli, V., Gozzo, F.C., Dale, C.S., Ferro, E.S., Guimarães, F.S. 2015 Anxiogenic-like effects induced by hemopressin in rats. Pharmacol. Biochem. Behav. $129,7-13$.

Gomes, I., Grushko, J.S., Golebienska, U., Hoogendoorn, S., Gupta, A., Heimann, A.S., Ferro, E.S., Scarlata, S., Frickers, L.D., Devi, L.A., 2009. Novel endogenous peptide agonists of the cannabinoid receptors. FASEB J. 23, 9,3020-9,3029.

Hama, A., Sagen, J., 2011. Centrally mediated antinociceptive effects of cannabinoid receptor ligands in rat models nociception. Pharmacol Biochem. Behav. 100 (2), 340-346. 
Han, Z.L., Fang, Q., Wang, Z.L., Li, X.H., Li, N., Chang, X.M., Pan, J.X., Tang, H.Z., Wang, R., 2014. Antinociceptive effects of central administration of the endogenous cannabinoid receptor type 1 agonist VDPVNFKLLSH-OH [(m)VD-hemopressin $(\alpha)]$, an $\mathrm{N}$-terminally extended hemopressin peptide. J. Pharmacol. Exp. Ther. 348, 2,316-2,323.

Heimann, A.S., Gomes, I., Dale, S.C., Pagano, R.L., Gupta, A., de Souza, L.L., Luchessi, A.D., Castro, L.M., Giorgi, R., Rioli, V., Ferro, E.S., Devi, L.A., 2007. Hemopressin is an inverse agonist of CB1 cannabinoid receptors. PNAS 104 (51), 20588-20593.

Herkenham, M., Lynn, A.B., Little, M.D., Johnson, M.R., Melvin, L.S., de Costa, B.R., Rice, K.C. 1990. Cannabinoid receptor localization in brain. PNAS 87 (5), 1932-1936.

Hofer, S.C., Ralvenius, W.T., Gachet, M.S., Fritschy, J.M., Zeilhofer, H.U., Gertsch, J., 2015. Localization and production of peptide endocannabinoids in the rodent CNS and adrenal medulla. Neuropharmacology 98, 78-89.

Kaiser, E., Colescott, R.L., Bossinger, C.D., Cook, P.I., 1970. Color test for detection of free terminal amino groups in the solid-phase synthesis of peptides. Anal. Biochem. 34 595-598.

Ledent, C., Valverde, O., Cossu, G., Petitet, F., Aubert, J.F., Beslot, F., Böhme, G.A., Imperato, A., Pedrazzini, T., Roques, B.P., Vassart, G., Fratta, W., Parmentier, M., 1999. Unresponsiveness to cannabinoids and reduced addictive effects of opiates in CB1 receptor knockout mice. Science 283 (5400), 401-404.

Manzanares, J., Corchero, J., Romero, J., Fernandez-Ruiz, J.J., Ramos, J.A., Fuentes, J.A., 1999. Pharmacological and biochemical interactions between opioids and cannabinoids. Trends Pharmacol. Sci. 20 (7), 287-294.

Massi, P., Vaccani, A., Romorini, S., Parolaro, D., 2001. Comparative characterization in the rat of the interaction between cannabinoids and opiates for their immunosuppressive and analgesic effects. J. Neuroimmunol. 117 (1-2), 116-124.

Matsuda, L.A., Lolait, S.J., Brownstein, M.J., Young, A.C., Bonner, T.I., 1990. Structure of a cannabinoid receptor and functional expression of the cloned cDNA. Nature 346, $561-564$.

Munro, S., Thomas, K.L., Abu-Shaar, M., 1993. Molecular characterization of a peripheral receptor for cannabinoids. Nature 365, 61-65.

Pacher, P., Batkai, S., Kunos, G., 2006. The endocannabinoid system as an emerging target of pharmacotherapy. Pharmacol. Rev. 58 (3), 389-462.

Pan, J.X., Wang, Z.L., Li, N., Han, Z.L., Li, X.H., Tang, H.H., Wang, P., Zheng, T., Fang, Q., Wang, R., 2014. Analgesic tolerance and cross-tolerance to the cannabinoid receptor ligand hemopressin, VD-hemopressin( $\alpha$ ) and WIN55,212 at the supraspinal level. Neurosci. Lett. 578, 187-191.

Pan, J.X., Wang, Z.L., Li, N., Zhang, N., Wang, P., Tang, H.H., Zhang, T., Yu, H.P., Zhang, R., Zheng, T., Fang, Q., Wang, R., 2015. Effects of neuropeptide FF and related peptides on the anticociceptive activities of VD-hemopressin(a) in naïve and cannabinoidtolerant mice. Eur. J. Pharmacol. 767, 119-125.

Pertwee, R.G., 1997. Pharmacology of CB1 and CB2 receptors. Pharmacol. Ther. 74, 129-180.
Petrovszki, Z., Kovacs, G., Tomboly, C., Benedek, G., Horvath, G., 2012. The effects of peptide and lipid endocannabinoids on arthistic pain at the spinal level. Anesth. Analg. $114,6,1346-6,1352$.

Rioli, V., Gozzo, F.C., Heimann, A.S., Linardi, A., Krieger, J.E., Shida, C.S., 2003. Novel natura peptide substrates for endopeptidase 24.15 , neurolysin and angiotensin-converting enzyme. J. Biol. Chem. 278, 8547-8555.

Scrima, M., Di Marino, S., Grimaldi, M., Mastrogiacomo, A., Novellino, E., Bifulco, M., D'Ursi, A.M., 2010. Binding of the hemopressin peptide to the CB1 receptor: structural insight. Biochemistry 49, 10449-10457.

Stone, L.S., Molliver, D.C., 2009. In search of analgesia: emerging roles of GPCRs in pain Mol. Interv. 9 (5), 234-251.

Straiker, A., Mitjavila, J., Yin, D., Gibson, A., Mackie, K., 2015. Aiming for allosterism: evaluation of allosteric modulators of CB1 in a neuronal model. Pharmacol. Res. 99, 370-376.

Szlavicz, E., Perera, P.S., Tomboly, C., Helyes, Z., Zador, F., Benyhe, S., Borsodi, A., Bojnik, E. 2015. Further characterization of hemopressin peptide fragments in the opioid and cannabinoid system. Anesth. Analgesia 121 (6), 1488-1494.

Tanaka, K., Shimizu, T., Yanagita, T., Nemoto, T., Nakamura, K., Taniuchi, K., Dimitriadis, F. Yokotani, K., Saito, M., 2014. Brain RVD-hemopressin, a hemoglobin-derived peptide, inhibits bombesin-induced central activation of adrenomedullary outflow in the rat. Br. J. Pharmacol. 171, 1,202-1,213.

Toniolo, E.F., Franciosi, A.C., Dale, C.S., 2014a. Hemopressin an inverse agonist of CB1 cannabinoid receptors reverses mechanical sensitivity on diabetes-induced neuropathy in mice. J. Diabetes Metab 5, 4.

Toniolo, E.F., Maique, E.T., Ferreira Jr., W.A., Heimann, A.S., Ferro, E.S., Ramos-Ortolaza, D.L., Miller, L., Devi, L.A., 2014b. Hemopressin an inverse agonist of cannabinoid receptors inhibits neuropathic pain in rats. Peptides 56, 125-131.

Van Sickle, M.D., Duncan, M., Kingsley, P.G., Mouihate, A., Urbani, P., Mackie, K., Stella, N., Makriyannis, A., Piomelli, D., Davison, S.J., Marnett, L.J., Di Marzo, V., Pittman, Q.J. Patel, K.D., Sharkey, K.A., 2005. Identification and functional characterization of brainstem cannabinoid CB2 receptors. Science 310, 329-332.

Xapelli, S., Agasse, F., Grande, S., Bernardino, L., Riberio, F.F., Schitine, C.S., Heimann, A.S. Ferro, E.S., Sebastiao, A.M., De Melo Reis, R.A., Malva, J.O., 2014. Modulation of subventricular zone oligodendrogenesis: a role for hemopressin? Front. Cell. Neurosci. 8, 59,1-59,9.

Zador, F., Kocsis, D., Borsodi, A., Benyhe, S., 2014. Micromolar concentrations of rimonabant directly inhibits delta opioid receptor specific ligand binding and agonist-induced G-protein activity. Neuroche. Int. 67, 14-22.

Zhang, J., Hoffert, C., Vu, H.K., Groblewski, T., Ahmad, S., O'Donnell, D., 2003. Induction of CB2 receptor expression in the rat spinal cord of neuropathic but not inflammatory chronic pain models. Eur. J. Neurosci. 17, 2750-2754. 